\title{
Digestion of polysaccharides, protein and lipids by adult cockerels fed on diets containing a pectic cell-wall material from white lupin (Lupinus albus L.) cotyledon
}

\author{
BY B. CARRÉ AND B. LECLERCQ \\ Institut National de la Recherche Agronomique, \\ Station de Recherches Avicoles, Centre de Tours-Nouzilly, France
}

(Received 25 October 1984 - Accepted 6 June 1985)

\begin{abstract}
1. The cell-wall material of white lupin (Lupinus albus L.) cotyledon is characterized by low contents of cellulose $(47 \mathrm{~g} / \mathrm{kg})$ and lignin $(17 \mathrm{~g} / \mathrm{kg})$ and a high content of pectic substances $(710 \mathrm{~g} / \mathrm{kg})$. The digestion of lupin cell-wall material by adult cockerels was estimated using gas-liquid chromatographic analyses of alditol acetates derived from polysaccharide sugars. The analyses were performed in the destarched water-insoluble fractions of feed and excreta. Digestibility measurements were carried out using a $3 \mathrm{~d}$ balance period including a $2 \mathrm{~d}$ feeding period and a $24 \mathrm{~h}$ final starvation period.

2. In the first experiment, six animals were given a diet containing $510 \mathrm{~g}$ white lupin cotyledon flour $/ \mathrm{kg}$ which was the only source of protein and cell walls in the diet. The apparent digestibility of cell-wall components was near zero.

3. In the second experiment, three diets were prepared by diluting a fibre-free basal $\operatorname{diet}(\operatorname{diet} A)$ by a semi-purified cell-wall preparation introduced at two different levels: $100 \mathrm{~g} / \mathrm{kg}$ (diet B) and $200 \mathrm{~g} / \mathrm{kg}$ (diet C). The semi-purified cell walls were prepared from the white lupin cotyledon flour used in the first experiment. The true digestibilities of polysaccharides measured in birds given diets $B$ and $C$ were near zero. It is suggested that the measurement of the neutral-detergent fibre (NDF) content according to Van Soest \& Wine (1967) is not a suitable procedure for estimating the undigestible fibre content in poultry nutrition as the cell-wall pectic substances are not included in the NDF measurement.

4. Addition of the semi-purified cell-wall preparation (Expt 2) resulted in a slight decrease in the apparent protein digestibility. This decrease might be explained by the addition of undigestible cell-wall protein.

5. Addition of the semi-purified cell-wall preparation (Expt 2) had no effect on the apparent lipid digestibility.

6. The metabolizable energy values of the basal diet fraction of diets $B$ and $C$ were calculated assuming that the added plant cell-wall fraction was of no energy value. These calculated values were similar to the measured metabolizable energy value of diet A (basal). Thus, the tested pectic plant cell walls seemed to act as a diluent. It is suggested that, on the point of the digestion yields, all types of plant cell walls would act as diluents, in poultry.
\end{abstract}

The term 'dietary fibre' is applied to a wide range of components exhibiting large variations in their chemical and physical characteristics (Selvendran, 1984) which probably explain variations in their nutritional effects (Kay, 1982). The susceptibility of fibre to microbial degradation depends on water solubility, nature of non-cellulosic polysaccharides (Bertrand et al. 1981; Nyman \& Asp, 1982; Van Soest, 1984) and lignin content (Morrison, 1972; Belyea et al. 1983). The microbial degradation of fibre in the hind-gut of non-ruminant animals leads to the production of absorbable volatile fatty acids which might provide available energy to the host (Parker, 1976; Imoto \& Namioka, 1978; Ruppin et al. 1980).

The fibre-induced microbial activity may influence faecal nitrogen excretion (Eggum $e t$ al. 1979) and can also promote bile acid deconjugation leading to a decrease of lipid utilization (Cole \& Fuller, 1984). Dietary fibres exhibit lipid adsorption and cation-exchange properties (Kay, 1982). Thus, dietary fibre can influence, directly or indirectly, the utilization of diets by non-ruminant animals. This topic has been previously studied in gallinaceous birds by measuring the digestibility of cellulose and pentosan (Bolton, 1955a, b; Almquist \& Halloran, 1971; Antoniou et al. 1981), of protein (Kibe et al. 1964; Sibbald, 1980b; Parsons et al. 1982) and lipids (Begin, 1961; Griminger \& Fisher, 1966; Kratzer et al. 1967; Akiba \& Matsumoto, 1980) and by measuring the metabolizable energy 
value of diets (Hedge et al. 1982). From these studies, it appears that the digestibility of fibre is generally low in poultry (von Vogt $\&$ Stute, 1971) compared with digestibilities measured in swine and rats (Keys et al. 1970; Nyman \& Asp, 1982). However, a sizeable proportion of pentosans has been shown to be digested in chickens (Bolton, 1955a, $b$ ) but the types of pentosans digested are still unknown. A precise knowledge of the type of fibre existing in diets is needed for a better understanding of their nutritional implications. In most of the previous studies, purified cellulose, purified hydrocolloids, cereal-related fibre or cellulose-rich fibre such as hull were involved. The effects of chemically purified substances remain questionable if no comparison is done with naturally occurring fibre. Hydrocolloids are very minor components in poultry diets. Barley and rye are the only usual ingredients known to contain a high proportion of hydrocolloids (Antoniou et al. 1981; De Silva et al. 1983). The cereal-related fibre or the cellulose-rich fibre are little susceptible to fermentative breakdown (Nyman \& Asp, 1982; Van Soest, 1984).

The present experiment was undertaken with the aim of testing in adult cockerels the effects of a cell-wall material rich in pectic substances and low in cellulose and lignin. These types of cell wall are expected to be highly susceptible to fermentative degradation (Morrison, 1972; Nyman \& Asp, 1982; Van Soest, 1984). Such cell walls, existing in leguminosae seed meal (Bailey, 1971; Brillouet \& Carré, 1983), are of wide occurrence in practical poultry diets. They exhibit high water-holding and cation-exchange capacities (Van Soest, 1984) and a strong ability to adsorb bile acids (Selvendran, 1978). The cell-wall material from white lupin (Lupinus albus L.) cotyledons, which were used in the present experiment, have been extensively studied from a biochemical stand-point (Carré et al. 1985). These cell walls are characterized by very low contents $(\mathrm{g} / \mathrm{kg})$ of cellulose $(50)$ and lignin (17) and a high content of pectic substances (710). The pectic substances of this cell-wall material contain a high proportion of neutral sugar chains, mainly composed of poorly branched $\beta-(1 \rightarrow 4)$ galactan associated with the rhamnogalacturonan moiety (Carré et al. 1985); biochemical investigations tended to demonstrate that galactan chains were quite labile and probably highly susceptible to fermentative breakdown (Carré et al. 1985). Thus, the cell-wall material of white lupin cotyledon seemed to be an appropriate material for testing the ability of cockerels to utilize fibre through their intestinal bacterial activity.

Two experiments were conducted using adult cockerels. In the first trial, animals were fed on a diet containing $510 \mathrm{~g}$ white-lupin-cotyledon flour $/ \mathrm{kg}$ as the only source of cell walls in the diet. The apparent digestibility of the cell-wall components was determined by measuring non-starchy sugars in the water-insoluble fractions of diets and excreta, using gas-liquid chromatography (GLC) of alditol acetates after acid-hydrolysis, and colorimetric determination of uronic acids. In the second experiment, a semi-purified cell-wall material was prepared from the white-lupin-cotyledon flour and was added as a diluent to a basal diet, free of fibre, at two different levels $(100$ and $200 \mathrm{~g} / \mathrm{kg}$ ). The true digestibility of lupin cell-wall components was measured using the same methods as in the first experiment. In addition, apparent digestibilities of protein and lipids, and apparent metabolizable energy either uncorrected (AME) or corrected for nitrogen equilibrium $\left(A M E_{N}\right)$ were measured to test the effect of fibre on the utilization of the basal diet fraction.

MATERIALS AND METHODS

Diets

Expt 1. Diet L (Table 1) contained a large quantity $(510 \mathrm{~g} / \mathrm{kg})$ of white-lupin-cotyledon flour which was prepared as follows. White Lupin (cv. Kalina) seeds $(100 \mathrm{~kg})$ were crushed using a ripple flow mill and the hull particles were removed by aspiration using a HEF dehuller (Hydrodynamique et Frottement, Saint Etienne). After bolting $(8 \mathrm{~mm})$, the 
Table 1. Composition and food intake $(\mathrm{g} / \mathrm{kg}$ air-dried material) of diet $\mathrm{L}$ (Expt 1) and diet A (basal diet, Expt 2)

\begin{tabular}{|c|c|c|c|}
\hline Ingredient & Origin & Diet $\mathrm{L}$ & Diet A \\
\hline $\begin{array}{l}\text { White-lupin (Lupinus albus)- } \\
\text { cotyledon flour }\end{array}$ & Lusignan, INRA & 510 & - \\
\hline Soya-bean-protein flour & Ralston Purina Co., St Louis, USA & - & 280 \\
\hline Sucrose & Beghin-Say, Thumeries & 200 & 317 \\
\hline Maize starch & Société des Produits du Maïs, Clamart & 200 & 317 \\
\hline Maize oil & - & 24 & 22 \\
\hline Animal-fat mixture & Mainguet, Tours & 50 & 48 \\
\hline Dicalcium phosphate & Aliphos, Belgium & 10 & 10 \\
\hline Sodium chloride & L. Clément, Solvay & 4.4 & $4 \cdot 4$ \\
\hline Mineral mixture* & UCAAB, Chateau-Thierry & 1 & 1 \\
\hline Vitamin Mixture $\dagger$ & $\begin{array}{l}\text { Prepared with products of } \\
\text { Hoffmann-La-Roche, Neuilly-sur-Seine }\end{array}$ & $0 \cdot 1$ & $0 \cdot 1$ \\
\hline Choline chloride $(50 \%)$ & AEC, Commentry & 0.5 & 0.5 \\
\hline $\begin{array}{l}\text { Apparent metabolizable } \\
\text { energy value }(\mathrm{MJ} / \mathrm{kg})\end{array}$ & & $15.09 \ddagger$ & $16 \cdot 34$ \\
\hline Nitrogen $\times 6.25(\mathrm{~g} / \mathrm{kg})$ & & 218 & 243 \\
\hline Cell walls $(\mathrm{g} / \mathrm{kg})$ & & $91 \S$ & $2 \|$ \\
\hline \multicolumn{4}{|l|}{ Food intake $(g / 2 d)$ : } \\
\hline Mean & & 222 & 125 \\
\hline SD & & 18 & 3 \\
\hline$n$ & & 6 & 6 \\
\hline
\end{tabular}

KI $1 \cdot 6$

* Supplied (mg/kg diet): $\mathrm{MnO}_{2} 168, \mathrm{ZnO} 105, \mathrm{FeSO}_{4} .7 \mathrm{H}_{2} \mathrm{O} 218, \mathrm{CuSO}_{4} .5 \mathrm{H}_{2} \mathrm{O} 35, \mathrm{CoCO}_{3} 0 \cdot 7, \mathrm{Na}_{2} \mathrm{SeO}_{3} 0 \cdot 5$, $\dagger$ Supplied $(\mathrm{mg} / \mathrm{kg} \mathrm{diet}):$ retinol $2 \cdot 4$, cholecalciferol $0 \cdot 025$, $\alpha$-tocopheryl acetate 10 , menadione sodium bisulphite 8 , riboflavin 4 , calcium pantothenate 4 , nicotinic acid 10 .

$\ddagger$ Calculated value.

$\S$ Measured as the residue obtained after lipid extraction and treatments by pronase and $\alpha$-amylase (EC $3.2 .1 .1)$.

\| Measured as insoluble non-starchy polysaccharides.

remaining hull particles were eliminated by hand and the cotyledon preparation was milled to pass through a $0.7 \mathrm{~mm}$ screen.

In association with the white-lupin-cotyledon flour, maize starch, sucrose, maize oil and animal fat were added (diet $\mathrm{L}$, Table 1). The white-lupin-cotyledon flour supplied all the protein and cell walls contained in diet $\mathrm{L}$.

Expt 2. Three experimental diets (A, B and C) were used. Diet A was composed of ingredients which contained only traces of cell-wall components (Table 1). Diets B and C were prepared by diluting diet $A$ with a semi-purified cell-wall preparation introduced at two different levels $(\mathrm{g} / \mathrm{kg})$ of $100(\operatorname{diet} \mathrm{B})$ and $200(\operatorname{diet} \mathrm{C})$ (Table 2). This preparation was isolated from the white-lupin-cotyledon flour used in Expt 1, by the following procedure: lipids and pigments of the cotyledon flour $(14 \mathrm{~kg})$ were extracted by soaking in 40 litres chloroform-methanol $(2: 1, \mathrm{v} / \mathrm{v})$ for $2 \mathrm{~h}$ at $20^{\circ}$. After two washings by filtration on sinters, the flour was treated again in the same way with methanol-water $(80: 20, \mathrm{v} / \mathrm{v})$, to remove the remaining pigments. Then, the defatted flour was successively rinsed with methanol and acetone, and dried in a drying-oven at $40^{\circ}$. The dry defatted flour $(11 \mathrm{~kg})$ was soaked in 80 litres 0.05-M-phosphate buffer, $\mathrm{pH} 7.5$, containing Streptomycine $(0.5 \mathrm{~g} / \mathrm{kg})$ and Benzylpenicilline $(0.5 \mathrm{~g} / \mathrm{kg})$ (Specia, Paris). The suspension was homogenized with a Turax homogenizer, and $4 \mathrm{~g}$ pronase (Boehringer, Mannheim, W. Germany) were added. The enzymic hydrolysis of proteins was performed under continuous stirring for $72 \mathrm{~h}$ at $20^{\circ}$. 
Table 2. Expt 2. Composition and food intake (dry-matter basis) of the diets used

\begin{tabular}{|c|c|c|c|}
\hline Diet... & A & B & $\mathrm{C}$ \\
\hline Basal diet $(\mathrm{g} / \mathrm{kg})$ & 1000 & 903 & 806 \\
\hline Semi-purified cell-wall preparation $(\mathrm{g} / \mathrm{kg})$ & 0 & 97 & 194 \\
\hline Apparent metabolizable energy value $(\mathrm{MJ} / \mathrm{kg})$ & $17 \cdot 26$ & $15 \cdot 85$ & $14 \cdot 14$ \\
\hline Nitrogen $\times 6.25(\mathrm{~g} / \mathrm{kg})$ & 257 & 241 & 227 \\
\hline Cell walls $(\mathrm{g} / \mathrm{kg})$ & $2 \dagger$ & $91^{*}$ & $181^{*}$ \\
\hline \multicolumn{4}{|l|}{ Food intake $(g / 2 d)$ : } \\
\hline Mean & 118 & 120 & 110 \\
\hline SD & 3 & 1 & 3 \\
\hline$n$ & 6 & 4 & 4 \\
\hline
\end{tabular}

* Content in semi-purified cell-wall preparation corrected for cytoplasmic protein existing in the preparation (see Table 3).

$\dagger$ Measured as insoluble non-starchy polysaccharides.

The mixture was then filtered through a nylon sieve $(5 \mu \mathrm{m})$ and rinsed twice with distilled water. The pronase treatment was repeated using the same procedure, but using only $2 \mathrm{~g}$ pronase. After being rinsed twice with distilled water, the residue was rinsed twice with methanol and acetone, dried at $40^{\circ}$ in a drying oven and ground to pass through a $0.7 \mathrm{~mm}$ screen. The final dry product $(1.3 \mathrm{~kg})$ represented the semi-purified cell-wall preparation.

\section{EXPERIMENTAL}

Twenty Rhode Island adult cockerels were used. They were reared in individual cages provided with plastic trays in order to collect the excreta during the collection period. Before the experiments, the animals were used routinely to measure the metabolizable energy values of practical poultry feedingstuffs. In Expt 1 , six animals (12 months of age) were fed on diet $\mathrm{L}$. The cockerels received the experimental diet ad lib. for a $3 \mathrm{~d}$ adaptation period and then for the $2 \mathrm{~d}$ of the feeding balance period. Adaptation and balance periods were separated by $24 \mathrm{~h}$ of starvation. Excreta were collected twice daily for the $2 \mathrm{~d}$ of the feeding balance period and for a following $24 \mathrm{~h}$ starvation period. Excreta were immediately stored at $-20^{\circ}$ after each collection. They were then freeze-dried, weighed and ground to pass through a $0.7 \mathrm{~mm}$ screen. In this experiment, only the apparent digestibilities of protein and cell-wall components were measured.

In Expt 2, fourteen animals ( 6 months of age) were used. Diet A was given to six animals, and each of the fibre-containing diets (B and $\mathrm{C}$ ) to four animals. Adaptation, feeding and collection of excreta were carried out as described in Expt 1 except that the animals were force-fed twice daily during the $2 \mathrm{~d}$ of the feeding balance period in order to obtain a very precise measurement of food consumption and to avoid any contamination of the excreta by feed spillage. The collection period lasted $53 \mathrm{~h}$, including a $24 \mathrm{~h}$ fasting period between the last force-feeding and the end of the collection. For force-feeding, the experimental diets were given with the following water additions (g water $/ \mathrm{kg}$ mixture): diet A 566, diet B 710, $\operatorname{diet} \mathrm{C} 771$. Metabolizable energy values and digestibilities of protein, lipids and cell-wall components were measured.

Analysis

Energy. The gross energy of food and excreta was measured using an automatic adiabatic bomb calorimeter (type CB-110; Gallenkamp, London). AME values and $\mathrm{AME}_{\mathrm{N}}$ were calculated as described by Hill \& Anderson (1958). 
Dry matter, $N$ and lipids. Dry matter was determined by drying at $103^{\circ}$ for $4 \mathrm{~h}$. $\mathrm{N}$ was measured using the Kjeldahl method. Faecal protein-N was estimated by the method of Terpstra \& de Hart (1974). Lipids were measured in diets by weighing the diethyl ether extract obtained by extraction for $6 \mathrm{~h}$ in a Soxhlet apparatus. An acidic treatment (Hakansson, 1974) was applied to excreta before lipid extraction by chloroform-methanol $(2: 1, \mathrm{v} / \mathrm{v})$ according to the method described by Folch et al. (1957). The lipids of excreta were then purified with benzene (Delpech et al. 1966) and weighed after removal of the remaining solvents.

Dietary fibre components. A purified cell-wall material was isolated from diet $\mathrm{L}$ and analysed as described previously (Carré et al. 1985).

In Expt 1, the individual cell-wall neutral sugars liberated by Saeman hydrolysis (Saeman et al. 1954) were analysed by GLC analysis of alditol acetates (Sawardeker et al. 1965), carried out on the residues obtained from diet $L$ and excreta after $\alpha$-amylase (EC 3.2.1.1) treatment (Brillouet \& Carré, 1983). The uronic acids were measured directly on food and excreta by the $m$-phenylphenol method (Blumenkrantz \& Asboe-Hansen, 1973) using concentrated sulphuric acid before analysis (El Rayah Ahmed \& Labavitch, 1977). The results of these analyses were used to calculate the apparent digestibility of cell-wall components.

In Expt 2, the cell-wall neutral-sugar analyses were conducted on residues obtained after pronase and $\alpha$-amylase treatments (Brillouet $\&$ Carré, 1983) for all samples of excreta and for diet A. The cell-wall neutral-sugar contents of diets $B$ and $C$ were calculated from the analysis of the semi-purified cell-wall preparation. The uronic acid content of diet $\mathrm{A}$ was obtained from the analysis of the residue obtained after pronase and $\alpha$-amylase treatments. The uronic acid contents of diets $\mathrm{B}$ and $\mathrm{C}$ were calculated from the analysis of the semi-purified cell-wall preparation.

The cellulose content of the semi-purified cell-wall preparation was expressed as the difference between the glucose contents obtained from the Saeman hydrolysate (Saeman et al. 1954) and trifluoroacetic-acid-hydrolysate (Albersheim et al. 1967). Cell-wall protein of the semi-purified cell-wall preparation was considered to be the pronase-resistant protein after additional pronase treatment using a high concentration of enzyme, as described previously (Brillouet \& Carré, 1983). The cytoplasmic protein content was calculated by difference between total and cell-wall protein. Hydroxyproline was determined after hydrolysis in $6 \mathrm{M}$-hydrochloric acid $\left(110^{\circ}, 24 \mathrm{~h}\right)$ using an LKB 4400 amino acid analyser, the optical density of the ninhydrin complex being read at $440 \mathrm{~nm}$.

Animals given diets $\mathrm{B}$ and $\mathrm{C}$ excreted polysaccharides which did not arise from the semi-purified cell-wall preparation. These polysaccharides were estimated from the polysaccharides excreted by animals fed on diet $\mathrm{A}$. This procedure allowed calculation of the true digestibility of cell-wall components of the semi-purified cell-wall preparation.

\section{Statistical analysis}

Differences between results were investigated using Student's $t$ test.

\section{RESULTS AND DISCUSSION}

\section{Dietary fibre composition}

Expt 1. Diet L (Table 1) contained $75.6 \mathrm{~g}$ cell-wall polysaccharides $/ \mathrm{kg}$, all originating from lupin-cotyledon flour. As expected, the monosaccharide composition of lupin cell-wall material present in diet L (Table 3) was almost identical to previously-reported results (Carré et al. 1985).

Expt 2. The basal diet (diet A) contained small amounts of insoluble non-starchy polysaccharides $(1.9 \mathrm{~g} / \mathrm{kg}$ dry matter). Maize starch, present in the basal diet, is known to 
Table 3. Composition of dietary fibres (dry-matter basis)

\begin{tabular}{|c|c|c|c|c|}
\hline & \multicolumn{2}{|c|}{$\begin{array}{l}\text { Purified cell-wall material } \\
\text { isolated from diet L } \\
\text { (Expt 1) }\end{array}$} & \multicolumn{2}{|c|}{$\begin{array}{l}\text { Semi-purified cell-wall } \\
\text { preparation introduced in } \\
\text { diets B and C (Expt 2) }\end{array}$} \\
\hline & $\mathrm{g} / \mathrm{kg}$ & Molar ratio & $\mathrm{g} / \mathrm{kg}$ & Molar ratio \\
\hline Rhamnose* & 2 & 2 & 12 & 5 \\
\hline Fucose & 1 & 1 & 4 & 2 \\
\hline Arabinose & 109 & 100 & 235 & 100 \\
\hline Xylose & 28 & 26 & 70 & 30 \\
\hline Mannose & Trace & - & Trace & -_ \\
\hline Galactose & 525 & 392 & 242 & 84 \\
\hline \multicolumn{5}{|l|}{ Glucose } \\
\hline Cellulosic & 47 & 35 & 91 & 32 \\
\hline Non-cellulosic & 9 & 7 & 4 & 1 \\
\hline Uronic acids & 110 & 76 & 188 & 60 \\
\hline \multicolumn{5}{|c|}{ Protein (nitrogen $\times 6.25$ ): } \\
\hline From cell wall $\dagger$ & 61 & & 33 & \\
\hline From cytoplasm & - & & 65 & \\
\hline Lignin & 17 & & nd & \\
\hline Minerals & $5 \S$ & & $13 \|$ & \\
\hline Total & 914 & & 957 & \\
\hline
\end{tabular}

nd, not determined.

* The monosaccharides are considered as anhydro-sugars.

+ Estimated as pronase-resistant protein.

\#stimated as the difference between total and pronase-resistant protein.

$\S$ Measured using X-ray dispersion micro-analysis.

II Measured by incineration.

Table 4. Expt 2. Excreta output of water-insoluble polysaccharides by adult cockerels fed on diet $A$ (basal diet)

(Mean values and standard deviations for six birds)

\begin{tabular}{|c|c|c|c|c|}
\hline & \multicolumn{2}{|c|}{$\begin{array}{c}\text { Intake } \\
(\mathrm{mg} / 2 \mathrm{~d})\end{array}$} & \multicolumn{2}{|c|}{$\begin{array}{l}\text { Excreta output } \\
\text { (mg/2 d) }\end{array}$} \\
\hline & Mean & SD & Mean & SD \\
\hline Rhamnose* & 1 & 0 & 6 & 2 \\
\hline Fucose & 2 & 0 & 7 & 1 \\
\hline Arabinose & 31 & 1 & 35 & 5 \\
\hline Xylose & 14 & 0 & 20 & 5 \\
\hline Mannose & 2 & 0 & 6 & 2 \\
\hline Galactose & 52 & 1 & 54 & 11 \\
\hline Glucose & 76 & 2 & 106 & 17 \\
\hline Uronic acids & 50 & 1 & 40 & 6 \\
\hline
\end{tabular}

* The monosaccharides are considered as anhydro-sugars.

contain fibre (Nyman \& Asp, 1982). However, the composition of the insoluble non-starchy polysaccharides from the basal diet (Table 4) was close to that of soya-bean cotyledon cell walls (Brillouet \& Carré, 1983). Therefore, it is likely that the main portion of insoluble non-starchy polysaccharides present in $\operatorname{diet} \mathrm{A}$ was derived from soya-bean-protein flour which might have been contaminated by remaining cell-wall material. 
Diets B and C (Table 2) contained a semi-purified cell-wall preparation obtained from white-lupin-cotyledon flour. The isolation procedure (solvent extractions and pronase treatments) of the semi-purified cell-wall preparation was as mild as possible. With respect to the large amount of flour to be treated, the isolation procedure was slightly different from the method used for isolation of small amounts of purified material (Carré et al. 1985); antibiotics were chosen as a bactericide instead of sodium azide, and a far lower pronase concentration was used (ten times less) than that used by Carré et al. (1985). The discrepancy between compositions of purified and semi-purified material (Table 3) may be explained by the modifications of the isolation procedure which probably allowed the emergence of some endogenous enzymic activities inducing the partial degradation of the cell wall. However, the sugar molar ratios did not change widely, except for galactose which strikingly decreased (Table 3). It is likely that only the galactose chains were degraded during the process. This may be related to the linear poorly-branched structure of the galactose backbone (Carré et al. 1985), which may result in its separate degradation. The selective decrease in galactose may be compared to the modifications of the cell walls of cotyledons of yellow lupin (Lupinus luteus) (Matheson \& Saini, 1977) and blue lupin (Lupinus angustifolius) (Crawshaw \& Reid, 1984), observed during the first days of the germination period. The cell walls of the semi-purified preparation were probably equivalent to cotyledon cell walls occurring naturally in germinated lupin seeds. Due to this modification, the composition of the semi-purified cell-wall preparation (Table 3 ) was similar to those observed for the cotyledon cell walls from other leguminosae used today in poultry feeding. Cotyledon cell walls of soya bean (Glycine max), smooth field pea (Pisum sativum) and broad bean (Vicia faba) contain about $(\mathrm{g} / \mathrm{kg}$ ): cellulose 100, uronic acids 150-200, neutral non-cellulosic polysaccharides $470-610$; these last polymers are mainly pectic polysaccharides composed of arabinose and galactose (Brillouet \& Carré, 1983). Consequently, the semi-purified cell-wall preparation used in the present experiment must be considered as a test material representative of a cell-wall material rich in pectic substances.

The semi-purified cell-wall preparation contained $33 \mathrm{~g}$ cell-wall protein $/ \mathrm{kg}$ and $65 \mathrm{~g}$ cytoplasmic protein $/ \mathrm{kg}$ which could not be removed during the isolation process. It can be noticed that the cell-wall protein decreased to the same extent as galactose, when compared with purified cell-wall material (Carré et al. 1985). This phenomenon could be related to the galactose-serine $O$-glycosidic links described by Lamport et al. (1973).

\section{Digestibilty of cell-wall components}

Expt 1. Apparent digestibilities of cell-wall components were nearly zero (Table 5). The digestibility values tended to be negative, indicating that non-dietary polysaccharides were probably excreted in addition to the lupin polysaccharides.

Expt 2. Cockerels fed on the basal diet (diet A) low in fibre excreted a slightly higher amount of insoluble non-starchy polysaccharides compared with the quantities ingested (Table 4). The neutral monomers involved in this additional excretion were rhamnose, fucose, xylose, mannose and glucose for which the highest negative apparent digestibility values were measured in Expt 1 . The origins of these non-dietary polysaccharides present in excreta were not investigated. However, it is interesting that they were detected in the water-insoluble fraction and could, therefore, arise from bacterial envelope residues. In birds fed on diet $A$, the excreted polysaccharides exhibited a composition quite similar to that of ingested polysaccharides (Table 4), indicating that the bulk of them was of dietary origin. Therefore, the amounts of non-lupin polysaccharides excreted by birds fed on diets B and $\mathrm{C}$ were estimated from the amounts of polysaccharides excreted by birds fed on basal $\operatorname{diet} \mathbf{A}$, on the basis of the basal diet intakes; this calculation was used to obtain the true digestibilty of lupin-cell-wall polysaccharides. 
Table 5. Digestibility of cell-wall polysaccharides in adult cockerels fed on diets containing fibres from white lupin (Lupinus albus) cotyledon

(Mean values and standard deviations)

\begin{tabular}{|c|c|c|c|c|c|c|}
\hline \multirow{3}{*}{$\begin{array}{c}\text { Diet... } \\
n \ldots\end{array}$} & \multirow{2}{*}{\multicolumn{2}{|c|}{ 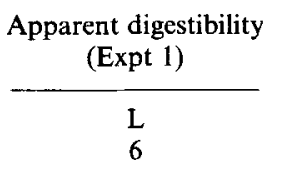 }} & \multicolumn{4}{|c|}{$\begin{array}{l}\text { True digestibility } \\
\text { (Expt 2) }\end{array}$} \\
\hline & & & \multicolumn{2}{|c|}{$\begin{array}{l}\text { B } \\
4\end{array}$} & \multicolumn{2}{|c|}{$\begin{array}{l}C \\
4\end{array}$} \\
\hline & Mean & SD & Mean & SD & Mean & SD \\
\hline $\begin{array}{l}\text { Rhamnose } \\
\text { Fucose } \\
\text { Arabinose } \\
\text { Xylose } \\
\text { Galactose } \\
\text { Glucose } \\
\text { Uronic acids }\end{array}$ & $\begin{array}{r}-0.262 \\
-0.480 \\
-0.021 \\
-0.044 \\
0.008 \\
-0.100 \\
-0.074\end{array}$ & $\begin{array}{l}0.226 \\
0.439 \\
0.042 \\
0.066 \\
0.067 \\
0.088 \\
0.048\end{array}$ & $\begin{array}{r}-0.160 \\
-0.264 \\
0.052 \\
0.019 \\
0.076 \\
-0.006 \\
0.073\end{array}$ & $\begin{array}{l}0.235 \\
0.136 \\
0.021 \\
0.028 \\
0.009 \\
0.055 \\
0.031\end{array}$ & $\begin{array}{r}0.139 \\
0.103 \\
0.009 \\
-0.040 \\
0.061 \\
0.036 \\
0.003\end{array}$ & $\begin{array}{l}0.128 \\
0.166 \\
0.061 \\
0.088 \\
0.028 \\
0.064 \\
0.064\end{array}$ \\
\hline Total & -0.016 & 0.053 & 0.050 & 0.012 & 0.025 & 0.045 \\
\hline
\end{tabular}

The results of Expt 2 were similar to those of Expt 1: the digestibility of the cell-wall preparation was very low. The values did not vary significantly with respect to the concentration of fibre inclusion levels $(100$ or $200 \mathrm{~g} / \mathrm{kg}$ ). The biochemical study of the lupin-cotyledon polysaccharides led to the hypothesis that they were not included in a resistant structure and could be easily degraded, especially for the galactose polymers (Carré et al. 1985). The lability of the galactose polymers was reflected by their degradation during the preparation of cell walls used in the present experiment. However, the naturally-occurring lupin cell-walls, rich in galactose polymers, were not digested by cockerels (Expt 1). The galactose polymers, which are branched on the rhamnogalacturonan backbones (Carré et al. 1985), could limit the enzymic degradation of the rhamnogalacturonan moiety. However, even after a wide degradation of galactose polymers, the digestion of lupin cell walls was not significantly improved (Expt 2).

From these observations, it may be assumed that the ability of adult cockerels to digest plant fibres is very low. This agrees with previous work involving chemical measurement of fibre digestibility in young birds (Bolton, 1955b; Antoniou et al. 1981; Longe et al. 1982). Hedge et al. (1982) claimed that young chicks could utilize about $150 \mathrm{~g} / \mathrm{kg}$ wheat straw but this conclusion was not supported by direct chemical measurements and was deduced indirectly from calculation of metabolizable energy values of mixed diets. However, it has often been reported that adult birds were able to digest a sizeable amount of pentosan (Bolton, 1955a, $b$; von Vogt \& Stute, 1974). In previously-published work, pentosan measurements were applied without previous fractionation to distinguish water-soluble and water-insoluble polysaccharides (Bolton, 1955a, $b$; von Vogt \& Stute, 1974) while, in the present study, the water-soluble polysaccharides were removed before analyses of the residues. As cereals formed the major part of the diets (Bolton, 1955a, $b$; von Vogt \& Stute, 1974), the water-soluble pentosans represented probably a sizeable proportion of the whole pentosans (D'Appolonia et al. 1971; Mares \& Stone, 1973). Therefore, the watersoluble pentosans could have been the digested fraction of the whole pentosans. This is supported by the fact that the highest pentosan digestibilities were obtained when using the cereal grain exhibiting the highest proportion of endosperm (wheat $v$. oat) (Bolton, 1955a). This observation must be related to the endospermic location of the water-soluble pentosans 
Table 6. Expt 2. Effect of the addition of the semi-purified cell-wall preparation on apparent protein digestibility in adult cockerels

(Mean values and standard deviations)

\begin{tabular}{|c|c|c|c|c|c|c|c|c|c|c|c|c|}
\hline \multirow{3}{*}{$\begin{array}{c}\text { Fibre } \\
\text { added } \\
\text { to basal } \\
\text { diet } \\
\text { (g/kg } \\
\text { dry } \\
\text { matter) }\end{array}$} & \multirow[b]{3}{*}{$n$} & \multirow[b]{3}{*}{$\operatorname{Diet} \dagger$} & \multirow{2}{*}{\multicolumn{2}{|c|}{$\begin{array}{c}\text { Total } \\
\text { nitrogen } \\
\text { intake } \\
(\mathrm{mg} / 2 \mathrm{~d})\end{array}$}} & \multicolumn{4}{|c|}{ Faecal N } & \multicolumn{4}{|c|}{ Apparent digestibility } \\
\hline & & & & & \multicolumn{2}{|c|}{$\begin{array}{r}\text { Total N } \\
(\mathrm{mg} / 2 \mathrm{~d})\end{array}$} & \multicolumn{2}{|c|}{$\begin{array}{l}\text { Corrected for } \\
\text { cell-wall N } \\
(\mathrm{mg} / 2 \mathrm{~d})\end{array}$} & \multicolumn{2}{|c|}{ Total N } & \multicolumn{2}{|c|}{$\begin{array}{l}\text { Corrected for } \\
\text { cell-wall } \mathrm{N} \ddagger\end{array}$} \\
\hline & & & Mean & SD & Mean & SD & Mean & SD & Mean & SD & Mean & SD \\
\hline 0 & 6 & A & 4852 & 133 & 551 & 45 & 551 & 45 & 0.886 & 0.007 & 0.886 & 0.007 \\
\hline 97 & 4 & B & 4648 & 29 & 548 & 35 & 486 & 35 & 0.882 & 0.008 & 0.894 & 0.008 \\
\hline 194 & 4 & $\mathrm{C}$ & 4003 & 116 & 535 & 18 & 419 & 17 & $0.866^{* *}$ & 0.005 & 0.892 & 0.005 \\
\hline
\end{tabular}

Mean value was significantly different from the diet A value: ${ }^{* *} P<0 \cdot 01$.

$\dagger$ For details, see Table 2.

† The cell-wall $\mathrm{N}$ (see Table 3 ) is considered as undigestible $\mathrm{N}$.

(Mares \& Stone, 1973). Moreover, it should be noted that starch can interfere with pentosan determinations (Tollier \& Riquet, 1980). As diets contain much higher amounts of starch than excreta, the pentosan digestibility values could be slightly overestimated.

The short transit time for cockerels (Sibbald, 1980a) and the separation mechanism located in the caecum-colon region which prevents large cell-wall particles from entering the caeca (Björnhag \& Sperber, 1977) probably explain the low ability of cockerels to digest plant cell walls.

It must be noted that $78 \%$ of white-lupin-cotyledon cell walls are solubilized (Carré et al. 1985) during the preparation of the neutral-detergent fibre (Van Soest \& Wine, 1967). It appears clearly that Van Soest \& Wine's (1967) procedure cannot be used for poultry to estimate the undegradable cell-wall content of foodstuffs which contain cell-wall pectic substances such as leguminosae seed meal (Brillouet \& Carré, 1983).

\section{Expt 2. Effect of fibres on the apparent protein digestibility}

Addition of the semi-purified cell-wall preparation lowered the apparent protein digestibility with a significant $(P<0.01)$ effect at the $200 \mathrm{~g} / \mathrm{kg}$ inclusion level (Table 6). The origin of the proteins which are responsible for this additional excretion remains questionable: they could come from bacterial, endogenous or dietary origin. First, the dietary origin must be considered, as the semi-purified cell-wall preparation contained $98 \mathrm{~g}$ protein $/ \mathrm{kg}$ (Table 3 ). It may be assumed that the cytoplasmic proteins present in the semi-purified cell-wall preparation (Table 3 ) were degraded to the same extent as the whole cotyledon proteins (Expt 1). The apparent digestibility (0.857) of lupin cotyledon proteins, measured in Expt 1, was similar to the apparent protein digestibility measured in cockerels fed on diet A (Table 6). Therefore, it is likely that the lupin cytoplasmic proteins from the semi-purified cell-wall preparation could not be responsible for variations in the apparent digestibility of whole proteins observed in Expt 2. Special attention must be given to the cell-wall protein. Most of the available published findings suggest that they could not be degraded. Considerable evidence exists for the occurrence of $O$-glycosidic links between protein (extensin) and polysaccharides of plant cell walls (Lamport, 1969; Lamport \& Miller, 1971; Lamport et al. 1973). Hydroxyproline, which is a good tracer of extensin (Lamport, 1969; Lamport \& Miller, 1971), was measured in the semi-purified cell-wall preparation and in one sample of excreta from a bird fed on diet $\mathbf{C}$. Ingestion and excretion of hydroxyproline were roughly 
Table 7. Expt 2. Apparent lipid digestibility and apparent metabolizable energy values uncorrected $(A M E)$ or corrected for nitrogen-equilibrium $\left(A M E_{N}\right)$ of the basal diet fraction (dry matter basis) of diets $A, B$ and $C$, calculated on the basis of no energy being supplied by added plant cell walls

(Mean values and standard deviations)

\begin{tabular}{|c|c|c|c|}
\hline $\begin{array}{c}\operatorname{Diet} \uparrow \ldots \\
n \ldots\end{array}$ & $\begin{array}{c}\text { A (basal) } \\
6\end{array}$ & $\begin{array}{l}B \\
4\end{array}$ & $\begin{array}{l}C \\
4\end{array}$ \\
\hline $\begin{array}{l}\text { Added plant cell walls }(\mathrm{g} / \mathrm{kg}) \ddagger \\
\text { AME }(\mathrm{MJ} / \mathrm{kg})\end{array}$ & 0 & 91 & 181 \\
\hline Mean & $17 \cdot 26$ & $17 \cdot 44^{*}$ & $17 \cdot 30$ \\
\hline SD & 0.11 & 0.11 & 0.09 \\
\hline $\begin{array}{l}\operatorname{AME}_{\mathrm{N}}(\mathrm{MJ} / \mathrm{kg}) \\
\text { Mean }\end{array}$ & 17.17 & $17 \cdot 39^{*}$ & $17 \cdot 27$ \\
\hline $\begin{array}{l}\text { SD } \\
\text { Annent linid digestibility }\end{array}$ & 0.08 & 0.13 & 0.11 \\
\hline Mean & 0.861 & 0.856 & 0.870 \\
\hline
\end{tabular}

Mean values were significantly different from basal diet $\mathbf{A}$ : ${ }^{*} P<0.05$

$\dagger$ For details, see Table 2.

$\ddagger$ Semi-purified cell-wall preparation corrected for cytoplasmic protein.

equivalent, confirming that a low digestibility of cell-wall protein may be expected. The apparent digestibility of the non-cell-wall protein was calculated by assuming that cell-wall protein is undigested (Table 6). It appears from this calculation that the addition of the semi-purified cell-wall preparation did not affect significantly the utilization of the non-cell-wall proteins. This conclusion is in agreement with the previous findings showing that the addition of cellulose powder induces only neglible variations in the apparent protein digestibility in poultry (Kibe et al. 1964; Sibbald, 1980 b; Parsons et al. 1982). However, it has been recently shown (Parsons et al. 1983) that the amount of faecal endogenous $\mathrm{N}$ excreted by poultry can be fibre-dependent. Therefore, the increased protein excretion induced by the addition of the semi-purified cell-wall preparation could also come from an increase in the faecal endogenous protein excretion. However, the fibres used in the experiment of Parsons et al. (1983) included purified pectin and as this material is watersoluble, its effect cannot readily be compared with the effect of the fibre studied in the present experiment.

\section{Expt 2. Effect of fibres on the apparent lipid digestibility}

Lipid digestibility did not differ significantly when birds were fed on either the basal diet $A$ or the lupin-fibre-supplemented diets B or C (Table 7). Similar results have been previously obtained in chickens fed on diets supplemented with cellulose or naturallyoccurring water-insoluble fibres (Akiba \& Matsumoto, 1980). Begin (1961) observed that the digestibility of diethyl ether extract increased as the feed concentration in cellulose was enhanced. But, in this experiment, the lipid content of diets increased with the cellulose concentration (Begin, 1961). Cherry \& Jones (1982), who found that the apparent digestibility of diethyl ether extract was decreased in hens by the supplementation of cellulose, related this effect to the reduction of the fat intake by hens fed on the cellulose-supplemented diet. 
Expt 2. Metabolizable energy values of fibre-supplemented diets

As expected, the dilution of the basal diet by the semi-purified cell-wall preparation induced a significant decrease of apparent metabolizable energy values (Table 2). The metabolizable energy value corresponding to the basal diet fraction of the fibre-supplemented diets $B$ and $\mathrm{C}$ was calculated on the basis of no energy being provided by the added plant cell walls. To obtain this estimation, the energy from the non-cell-wall protein present in the semi-purified cell-wall preparation (Table 3) was taken into account. A metabolizable energy value of $15.40 \mathrm{MJ} / \mathrm{kg}$ was assumed for this protein by applying the AME value $(17.97 \mathrm{MJ} / \mathrm{kg})$ of bean protein given by Titus (1957), corrected by the apparent digestibility coefficient $(0.857)$ of lupin protein measured in Expt 1 . Using this procedure, the calculated $A M E$ and $A M E_{N}$ values of the basal diet fraction of diets $B$ and $C$ were similar to the measured energy values of the basal diet (diet A) (Table 7). These findings are in agreement with the results of the digestibility measurements showing no significant effect of added lupin fibre on protein and lipid apparent digestibilities and very low digestion of lupin fibre components.

In conclusion, the tested water-insoluble fibre which was rich in pectic substances and low in cellulose acted, in our experiments, as a diet-diluting factor. This result is quite similar to those of previous experiments reported in the literature. It must be noted that, from a chemical point of view, the fibre tested in the present experiment differed from the water-insoluble fibres tested elsewhere. Therefore, the effects of dietary water-insoluble fibres on digestion in poultry seem to be independent of the chemical characteristics of the fibres. A new model for $A M E_{N}$ prediction of poultry diets based on the principle of the diluting effect of water-insoluble fibre has been successfully formulated (Carré et al. 1984).

As reported in the literature (Griminger \& Fisher, 1966; Kratzer et al. 1967; Antoniou et al. 1981), the effects of dietary water-soluble fibre seem to differ from a simple diluting effect. There is a lack of information concerning their degradation in the digestive tract of poultry. Investigations in this field are now in progress in our laboratory.

The authors are grateful to Mrs L. Derouet (INRA, Nouzilly) for technical assistance and to Mr Melsion (INRA, Nantes) for providing the white-lupin-cotyledon flour. The authors thank Dr M. Picard (INRA, Nouzilly) for improving the English of this paper.

\section{REFERENCES}

Akiba, Y. \& Matsumoto, T. (1980). Journal of Nutrition 110,1112-1121.

Albersheim, P., Nevins, D. J., English, P. D. \& Karr, A. (1967). Carbohydrate Research 5, 340-345.

Almquist, H. J. \& Halloran, H. R. (1971). Poultry Science 50, 1233-1235.

Antoniou, T. C., Marquardt, R. R. \& Cansfield, P. E. (1981). Journal of Agricultural and Food Chemistry 29, $1240-1247$.

Bailey, R. W. (1971). In Chemotaxanomy of the Leguminosae, pp. 503-541 [J. B. Harborne, D. Boulter and B. L. Turner, editors]. London and New York: Academic Press.

Begin, J. J. (1961). Poultry Science 40, 892-900.

Belyea, R. L., Foster, M. B. \& Zinn, G. M. (1983). Journal of Dairy Science 66, 1277-1281.

Bertrand, D., Brillouet, J. M., Rasper, V. F., Bouchet, B. \& Mercier, C. (1981). Cereal Chemistry 58, $375-380$.

Björnhag, G. \& Sperber, I. (1977). Swedish Journal of Agricultural Research 7, 57-66.

Blumenkrantz, N. \& Asboe-Hansen, G. (1973). Analytical Biochemistry 54, 484-489.

Bolton, W. (1955a). Journal of Agricultural Science, Cambridge 46, 119-122.

Bolton, W. (1955 b). Journal of Agricultural Science, Cambridge 46, 420-424.

Brillouet, J. M. \& Carré, B. (1983). Phytochemistry 22, 841-847.

Carré, B., Brillouet, J. M. \& Thibault, J. F. (1985). Journal of Agricultural and Food Chemistry 33, $285-292$.

Carré, B., Prévotel, B. \& Leclercq, B. (1984). British Poultry Science 25, 561-572.

Cherry, J. A. \& Jones, D. E. (1982). Poultry Science 61, 1873-1878.

Cole, C. B. \& Fuller, R. (1984). British Poultry Science 25, 227-231. 
Crawshaw, L. A. \& Reid, J. S. G. (1984). Planta 160, 449-454.

D'Appolonia, B. L., Gilles, K. A., Osman, E. M. \& Pomeranz, Y. (1971). In Wheat: Chemistry and Technology, pp. 301-392 [Y. Pomeranz, editor]. St Paul, Minnesota: American Association of Cereal Chemists Inc.

Delpech, P., Guezel, M. \& Leclercq, B. (1966). Revue Française des Corps Gras 10, 1-6.

De Silva, S., Hesselman, K. \& Aman, P. (1983). Swedish Journal of Agricultural Research 13, $211-219$.

Eggum, B. O., Fekadu, M. \& Wolstrup, J. (1979). Journal of the Science of Food and Agriculture 30, $177-184$.

El Rayah Ahmed, A. \& Labavitch, J. M. (1977). Journal of Food Biochemistry 1, 361-365.

Folch, J., Lees, M. \& Sloane-Stanley, G. H. (1957). Journal of Biological Chemistry 226, 497-509.

Griminger, P. \& Fisher, H. (1966). Proceedings of the Society for Experimental Biology and Medicine 122, $551-553$.

Hakansson, J. (1974). Swedish Journal of Agricultural Research 4, 33-47.

Hedge, S. N., Rolls, B. A. \& Coates, M. E. (1982). British Journal of Nutrition 48, 73-80.

Hill, F. W. \& Anderson, D. L. (1958). Journal of Nutrition 64, 587-603.

Imoto, S. \& Namioka, S. (1978). Journal of Animal Science 47, 467-478.

Kay, R. M. (1982). Journal of Lipid Research 23, 221-242.

Keys, J. E., Van Soest, P. J. \& Young, E. P. (1970). Journal of Animal Science 31, 1172-1177.

Kibe, K., Tasaki, I. \& Saito, M. (1964). Japanese Journal of Zootechnical Science 35, 159-166.

Kratzer, F. H., Rajaguru, R. W. A. S. B. \& Vohra, P. (1967). Poultry Science 46, 1489-1493.

Lamport, D. T. A. (1969). Biochemistry 8, 1155-1163.

Lamport, D. T. A., Katona, L. \& Roerig, S. (1973). Biochemical Journal 133, 125-131.

Lamport, D. T. A. \& Miller, D. H. (1971). Plant Physiology 48, 454456.

Longe, O. G., Norton, G. \& Lewis, D. (1982). Journal of the Science of Food and Agriculture 33, $155-164$.

Mares, D. J. \& Stone, B. A. (1973). Australian Journal of Biological Sciences 26, 793-812, 813-830.

Matheson, N. K. \& Saini, H. S. (1977). Phytochemistry 16, 59-66.

Morrison, I. M. (1972). Journal of the Science of Food and Agriculture 23, 455-463.

Nyman, M. \& Asp, N. G. (1982). British Journal of Nutrition 47, 357-366.

Parker, D. S. (1976). British Journal of Nutrition 36, 61-70.

Parsons, C. M., Potter, L. M. \& Brown, R. D. (1982). Poultry Science 61, 939-946.

Parsons, C. M., Potter, L. M. \& Brown, R. D. (1983). Poultry Science 62, 483-489.

Ruppin, H., Bar-Meir, S., Soergel, K. H., Wood, C. M. \& Schmitt, M. G. (1980). Gastroenterology 78, $1500-1507$.

Saeman, J. F., Moore, W. E., Mitchell, R. L. \& Millet, M. A. (1954). Journal of the Technical Association of the Pulp and Paper Industry 37, 336-343.

Sawardeker, J. S., Sloneker, J. H. \& Jeanes, A. (1965). Analytical Chemistry 37, 1602-1604.

Selvendran, R. R. (1978). Chemistry and Industry no. 12, 428-430.

Selvendran, R. R. (1984). American Journal of Clinical Nutrition 39, 320-337.

Sibbald, I. R. (1980a). Poultry Science 59, 374-377.

Sibbald, I. R. (1980 b). Poultry Science 59, 836-844.

Terpstra, K. \& de Hart, N. (1974). Zeitschrift für Tierphysiologie, Tierernährung und Futtermittelkunde 32, $306-320$.

Titus, H. W. (1957). Cited by Vohra, P. (1972). World's Poultry Science Journal 28, $204-214$.

Tollier, M. T.\& Riquet, A. M. (1980). In Les Polymères Végétaux: Polymères Pariétaux et Alimentaires non Azotés, pp. 156-175 [B. Monties and C. Costes, editors]. Paris: Bordas.

Van Soest, P. J. (1984). Proceedings of the Nutrition Society 43, 25-33.

Van Soest, P. J. \& Wine, R. H. (1967). Journal of the Association of Official Analytical Chemists 50, 50-58.

von Vogt, H. \& Stute, K. (1971). Archiv für Geflügelkunde 35, 29-35.

von Vogt, H. \& Stute, K. (1974). Archiv für Geflügelkunde 38, 117-118. 